\title{
Scardova's Theatre and the Academies
}

Mauda Bregoli-Russo

In Special Collections at the University of Illinois at Urbana-Champaign are found two comedies bound together, one maritima (maritime) and one pastorale (pastoral), respectively La nave (the Ship) and Il cornacchione (the crow), both written by Pietro Martire Scardova, ${ }^{1}$ a priest of Reggio, a town near Ferrara in Italy.

In view of the recent studies on pastoral theater and Sannazaro (Origini del dramma pastorale in Europa), a careful inquiry into Scardova's production is in order, for the purpose of shedding light on a regional theatrical experiment.

To this end I have analyzed these two comedies, and have reviewed the cabalistic and hermetic treatise on numerology by Scardova, L' 8 troppo, presently held at the Antonio Panizzi Library in Reggio, Italy. I will first treat the plays of Pietro Scardova and then his background within the Italian academic traditions.

La nave and Il cornacchione, written and probably staged in Reggio before $1550,{ }^{2}$ represent a significant contribution to the history of the Commedia dell'arte. This was a period, in fact, of intense debate regarding the pastoral/satyric genre (See Gian Battista Giraldi Cinzio). Although La nave and Il cornacchione are classified as standard types because both are divided into five acts preceded by a Prologue (a Mermaid and a Sea monster in La nave and a Satyr in Il cornacchione), both comedies also present some novelties:

1) the action of La nave takes place exclusively on the deck of a ship.

2) In contrast to serious pastoral drama in Ferrara, both have comical characters: Bromio in La nave and Summonzio in Il cornacchione. In this respect they are similar to Ruzante's La Pastoral, Calmo's egloghe, and the theatrical production of Siena's Accademici Rozzi and Insipidi (see Tregiani, Agolini, Cacciaconti).

3) Moreover, the canovacci ("canovaccio," in the Comedy of Art's terminology, is a "progressive description of the scenic action through the use of a special form of writing, metawriting." It is also a mirror of the interdependent relationship of the characters) show the typical fixed outline that distinguishes the later written tradition of the Commedia dell'arte. 
There are standard fixed parts, the Innamorati, the Elders, the clownish servants (called Zanni), as well as variable parts. As played by the Compagnia di S. Rocco, ${ }^{4}$ the theatrical company available to Scardova for his works ( $L$ ' 8 troppo B.iir), the fixed parts were three: youths (Isandro and Acrisio in La nave, Meliseo, Dameta, and Silvaggio in Il cornacchione), an old man (Thoante in La nave and Cloneo in Il cornacchione), and finally a clown (Bromio and Summonzio). Such characters are, in fact, present in both works, while shipmen in La nave and sheperds and the old magician Corina in Il cornacchione make up the variable (mobili) characters.

There is a discrepancy between characters as listed in the printed first edition and in the manuscript of $I l$ cornacchione. The Pastor giovane, Silvaggio in the manuscript, became Summonzio in the printed edition. Obviously, the manuscript, being drawn in Scardova's own hand, is of greater significance. In reading $I l$ cornacchione we find that Silvaggio, Pastor giovane, is the Innamorato of the nymph Argilla (Il cornacchione $11.51,53)$, just as Meliseo, Pastor giovane, is the Innamorato of the nymph Lidia, and Dameta, Pastor giovane, is the Innamorato of the nymph Orithia 4: one may conclude that for Scardova giovane is equivalent to Innamorato. Giovane is, therefore, a metaword pregnant with significance: it doesn't just mean chronological age but it also implies the function and the role of Innamorato.

At variance with tradition is the fact that the words "Maritime" and "Pastoral" are linked with stage requirements, which in turn influence the setting and scenery. Scardova was not trying to invent a new genre, but rather to write different types of comedies. To quote Scardova himself:

In Rome comedies were given various names according to the subjects that they deal with, such as Stataria (simple plot), Motoria (complicated plot), Mista (mixed plot), Togata (dealing with Roman subjects), Palliata (dealing with Greek subjects), Tabemaria (of events happening in tavem), giuocosa (Playful), Praetestata (an item of Roman clothing), and Attellana [sic] a fabula with fixed characters, from Atella in Campania). ${ }^{5}$

Similarly Tito Giovanni Scandianese (1515-1582), a scholarly contemporary of Scardova from Scandiano grouped several types of plays within the category of comedy (Tiraboschi, Storia 7.3: 1154-57). In a letter he noted the staging of Pastorali in several cities: "While I was in Modena, Reggio, Carpi and other places of Lombardy, comedies were staged almost yearly of either Pastoral and Civilian type, which I composed with new and honest intermezzi.",

Scardova was not an isolated provincial. It is evident that there were theatrical exchanges between Reggio and Milan, since Giuseppe Betussi, 
a member of the Fenici Academy in Milan (and also a friend and a correspondent of Scandianese), ${ }^{7}$ wrote a sonnet that was printed in the edition of La nave and Il cornacchione. the sonnet praises Scardova for the style of his vernacular, which may, he claims, be favorably compared to the best Greek and Latin. the comedies are also praised for avoiding the common trend, and for discriminating selection of classical models:

the best of Greek and Latin writers,

as well the worthy Italian, should all take second

place to your fair style, since you have shown

how to rightly claim immortal honors,

How comedy may stop following trend;

Knowledgeable of what others did,

Like a bee you pick the best among the flowers. ${ }^{8}$

Scardova himself was not the kind of scholar to stay rooted in provincial Reggio, his own city. Rome was his alternate abode, and he had also been in Venice and Naples. As he wrote in L'8 troppo:

Many people, perhaps moved by false pity, exhort me to remain in Rome and make myself familiar at Court and with those highborn persons, so that perhaps I could be noticed. . . . I won't forget that in Venice, a famous professor of Astronomy, to whom I gave the year and the date and the precise hour of my birth, very kindly figured my ascendent. . . I was talking about this horoscope one moming while travelling on horseback from Rome to Alba with my very virtuous Mister Gabriello Roberti; at Marino, where the road turns toward Naples, a hermit joined us. ${ }^{9}$

$$
\text { (B.iir, B.iiv, B.iiiv and C. } r \text { ) }
$$

By the late Cinquecento it is no longer the individual but the Academiesthemselves that reflect this need for an international culture in preference to urban isolation. Scardova was a member of the Accademia dei Trasformati, whose emblem was Prometheus and whose motto was "By this means transformed to a better life." Established before 1543, the Academy promoted banquets, organized comedies and other works, and took care of stage settings. L' 8 troppo, Scardova's treatise which addresses the members of the Academy, gives us an interesting glimpse of Italian cultural life in the late Cinquecento:

It has been many years since you founded your own scholarly Academy on the rock of virtue. Greek and Latin studies and the other Sciences all find completion in it. It has become such as could compare with any other that presently enjoys the respect of the highest people and wisest scholars. Wishing to witness such precious magnificence, I was introduced by the most noble and knowledgeable Transformed, the knight Mr. Gazuoli, mirror of virtue and light of 
worthiness. While admiring the beauty of the place, immediately I perceive your fine Impresa portraying mightly father Prometheus, your protector, who with a torch was infusing life into a figure he himself had formed with his own hands, and under whose feet was found the motto, "by means of this tranformed to better life." I praised the Impresa and determined that under the allegory poorly understood by the ancient, Prometheus simply reflected the appearance of the true almighty God, the only maker of man and of all things human and divine. This, my first introduction, occurred in the year 1543, under the happy lordship of the most illustrious Count Tedaldo Canossa, a most worthy Prince of such laudable group. therefore in such a happy place and wherever you may be, lift your acclamation to the sky, and on the wings of virtue fly to where life is eternal. And moreover, with fine comedies and rich banquets and beautiful compositions outshine any other and always endeavour to entertain the very noble ladies of Reggio and make their glory outshine the sun. ${ }^{10}$

A scholar could belong to more than one Academy. Thus Scardova, in addition to being one of the Trasformati, was also a member of the Academy of the Accesi. Several Academies could exist in the same city (Siena hosted the Rozzi, the Insipidi, and the Intronati; Milan hosted the Fenici and Trasformati, and so forth). Reggio also hosted the Academy of the Accesi, about whom a whole volume was written by the historian Giovanni Guasco. My research failed to find any papers of the Academy of Trasformati in Reggio. the only testimonial about it is to be found in the words of Scardova in L'8 troppo. A better known Academy of Trasformati, in Milan, was mentioned by Domenichi in his Ragionamento sulle Imprese. ${ }^{11}$ It must have been very powerful: even Ortensio Lando feared their opinion about his Paradoxes written for Boccaccio's Decameron: “. . . I greatly fear Lucca's Balordi may make fun of my writings, I become pale when I think of Pisa's Sordi and I live in the terror that the Elevati of Ferrara may, with their sharp writing, shame me. Nor do I feel less fright in my breast from those in Milan [(Trasformati], newly founded by Mister Renato Trivulzio."(M.4r; see also Tiraboschi, Storia 7.1: 171).We do not know for sure whether the Reggio Trasformati were a branch of the Milanese Trasformati. But we know there were numerous cultural relations between the two cities. It is well known that Renaissance Academies were centers of institutional culture, competing with the courts and possessing some power to print theatrical works, to prepare theatrical scenery, and to stage dramas.

I have found evidence that Scardova's treatise $L$ ' 8 troppo is not simply fanciful, but contains actual information. In L' 8 troppo Scardova describes a feast prepared in Reggio for the coming of the Emperor Charles V:“ ... in the year MDXXXIII, on August 17, the tragedy of St. Rocco was reverently performed by the worthy company of the Saint in the square at 
Reggio. And it was my work, and those who recited it were all gentlemen and among the highest in the City, and most of them still live. . ."12 The historian Guido Panciroli of Reggio, writing at the end of the 16th century, enlarges the above description, thereby adding authenticity to the emblematic treatise $L^{\prime} 8$ troppo:

... with a marvellous show St. Rocco's deeds were played in Reggio, and it was marvellous to see at the beginning a cloud descend from heaven and remain suspended, by the use of threads so thin that they could not be seen, seemingly hanging in the middle of the sky; a Vestal came out of it and recited a Prologue, and then it slowly disappeared. Afterwards, the seizing of a castle provided enjoyment to the spectators through the enactment of a battle, and a fake elephant appeared so alive in his movements that not only the townspeople, but many of the outsider who had flocked in to see it highly praised the show. . . ${ }^{13}$

Panciroli, again describing the triumphal apparatus for the visitation by Alfonso II of Este, wrote:

... Under the Arch two donzels attircd as nymphs threw flowers on Alfonso's vest. . . . In front of the citadel one could see Andromeda among mermaids chained to a rock. the appearante of the monster coming out of the sea to devour her was marvellous, and Perseus was fantastically supported in mid-air by Pegasus, in such a fashion that the workings that kept it suspended were hardly visible. then, the noise of artillery having come to a halt, a young man crowned with laurel [Scardova] ${ }^{14}$ holding an arrow in his right hand and the head of Medusa in his left, said a few things in praise of Alfonso and of the house of Este. $^{15}$

the castle, the cloud, the Vestal, and above all the elephant, bring back to mind the intermezzi described by Serlio for the stage at Vicenza: "For in Vicenza, the richest and proudest among the cities of Italy, I built an auditorium and stage of wood, perhaps-nay, without doubt-the largest in our age, where marvellous intermezzi were presented, with chariots, elephants, and diverse morris dances ..." (Hewitt 25). the mermaid and sea monster bring to mind the Prologues in verse and in prose of La nave. It is also likely that Scardova's maritime comedy had its own stage set. the inventories in the 17 th-century Scenari inediti della Commedia dell' Arte, by Basilio Locatelli (XXX), also cited by Ferdinando Neri (19-20), list Scardova's stage set.

If we accept that La nave had its own scenery, certainly we may hypothesize that Il cornacchione had its own too, since the two works are so closely related, not only in the fixed parts of the youths and old man but expecially in the parallel comic parts of Bromio in La nave and Summonzio in Il cornacchione. During the tempest, Bromio dreams of revelling, and remembers foods and drinks tasted while on his trips. He enumerates the 
specialities of each country, according to the literary technique of catalogs so dear to 16th-century's scholars such as Ortensio Lando:

And after this the wine of Nicaria induces ecstasy in me... O mighty power, o sweetest preciousness, o best of best, the wine I tasted in Scarpanto harbor ... and blessed be the South wind whose breath once propelled me to Madera, an island more than a hundred miles distant from the continent. there I ate the plumpest quails, the best in the whole world. And there also are to be found white peacocks, which when eating them, kings, nay, emperors, would lick their own fingers. Praised be cabbages, and turnips, and cantaloupes of Chioggia. And nothing but good will I say of the pears and apples and figs of Zafalonia [sic] and I love the fish of Stampalia, particularly I like those fish when fried in oil of Corfu. More than willing am I to eat sardines from Lissa, but by God, morsels of meat from Termia are so tasty that gluttons would eat bellyfulls of them. ${ }^{16}$

In a similar vein Summonzio in $I l$ cornacchione gives in to the pleasure of enumeration when writing his hymn to Bacchus and leisure:

Bacchus, Bacchus be thanked always, since I have found a flagon. I feel eternally obliged to this gentle God whom I understand was the very first to find wines. And therefore wine and cask and barrel and flagon and pitcher and gourd, and a thousand other good things are very useful to a man's life.... If I had found this flagon I would set on fire all these mountains and woods and fields and villas and houses and hovels and huts, and sheperds. Nor would I want ever to be found again hoes and spades and ploughshares, which, through their being lost, might aid those who, like me, don't care to work. ${ }^{17}$

La nave and Il cornacchione are all that remains of the theatrical production of Pietro Martire Scardova. these plays have been mentioned in two recent publications, one on the theater in Reggio Emilia, and the other on the sylvan scene in the Italian Renaissance (Romagnoli and Garbero, Teatro 180-207; Pieri, La scena 130-132). In both works Scardova received mixed reviews. He is praised for the novelty his use of of the maritime and pastoral conventions in the comedies. However, the two works are considered of only limited literary value.

Prior to this recent notice, Enrico Carrara (312) had attemped a comparison with Sannazaro's Piscatorial Eclogues, and the critics Giovanni Crocioni ("Per una fonte" 926-979) and Francesco Flamini (487) even considered the possibility that the pastoral comedy Il cornacchione was one of the sources for Tasso's Aminta, due to the similarities in plot. these comparisons with Sannazaro and Tasso fail to fully persuade the critical reader: "Maritime" or "of the sea" is in fact quite different from "Piscatorial" that is, "of the fish." And when the two texts are examined carefully it becomes very difficult to support the claim of a literary link between a 
poetic jewel like Tasso's Aminta and a modest work such as Scardova's Il cornacchione.

Nevertheless, novelties in Scardova's theatrical production do exist. I have tried to show them by using an approach based on commentaries of the Italian Academy system. the Italian Academies of the Renaissance were particularly interested in theatrical productions, including the organization of troupes of comedians, the staging of plays and the building of theaters. It should be remembered that the first Italian theater, Vicenza's Olimpico, was erected by Palladio in 1585 with the subsidy of the Accademia degli Olimpici. the Academy of Argonauts in Casale Monferrato specialized in the printing of nautical eclogues to be performed on stage. One of the endeavours of the Academy of Trasformati in Reggio was to stage comedies, as Scardova remarked in his cabalistic treatise $L$ ' 8 troppo. Even the Academy of Fenici in Milan took a keen interest in theatrical works, and one of its illustrious members, Giuseppe Betussi, graciously wrote a sonnet in honor of Scardova's comedies.

Considering the academic interest in theatrical productions, in contrast with the previous tradition of simple readings, and the availability of canovacci, which gave a sketch of plot and characters, Tasso may have taken some simple inspiration for plot or staging ${ }^{18}$ from Scardova's works. ${ }^{19}$

\section{University of Illinois at Chicago}

\section{NOTES}

1 For bibliographical information about Pietro Martire Scardova (1501?-1580), see Fontanini 1: 450.

2 L'8 troppo Br: "v'è chi dice, che le mie Comedie, come il Nauta, il Camello, l'Arconisba, il Morro, il Cornacchione, l'Agricchia, e il Misantropo, son belle sí, e di gran spasso, ma che non hanno sale, né pescano a fondo." the Ship and the Crow are quoted in $L^{\prime} 8$ troppo edited in 1550.

3 Zorzi 430: "Il canovaccio è, in sostanza, una descrizione progressiva dell'azione scenica, attuata mediante uno speciale tipo di scrittura (Metascrittura, appunto). . . ." Page 434 illustrates a standard canovaccio (see Appendix).

4 Scardova, L'8 troppo B.iir: . . . recitata la Tragedia di San Rocco dalla valorosa Compagnia del detto Santo. ..."

5 I have reviewed the manuscript of $I l$ cornacchione at the Antonio Panizzi Library in Reggio. the same remark has been made by Crocioni ("Pietro Martire" 373).

6 Scardova, Due commedie, Dedicatory letter ("Al Magnifico, et reverendo Signor Vincenzo Fossi Canonico di Reggio), 1.2v: “. . . appresso i Romani la comedia era variamente chiamata con quei nomi coi quali ella abbracciava le cose a lei aspettanti, cioè era detta Stataria, Motoria, Mista, Togata, Palliata, Tabemaria, Giuocosa, Pretestata, e Attellana." 
7 Tiraboschi, Biblioteca 44: "Le lettere dello Scandianese . . ci mostrano ch'egli era corrispondente ed amico di molti uomini dotti ed illustri di quell'età, come del Card. Cristoforo Madrucci Vescovo e Principe di Trento, di Giuseppe Betussi. . .."

8 Scardova, Due comedie $1 v$ (Il Betussi a M. Pietro Martire Scardova):

I buoni greci, e i latin migliori,

Non che i degni volgari, al bel stil vostro

Cedin, Scardova pur, c'havete mostro,

come si paggia a gli immortali honori,

Come il comico uscir de l'uso fuori

Voi conoscendo quel, che gli altri opraro,

Com'Ape va di fior scegliendo il meglio . . . (1-5,9-10).

9 Scardova, L'8 troppo B.iiv, B.iiiv, Cr: "molti altri mossi peraventura da non finta charità dicono ch'io dovrei star a Roma, e pratticar ivi quelle Corti, e quelle persone grandi, che forse riuscirei huomo signalato. . . . Non mi scordo che in Venezia un gran professore di Astronomia, cui datogli l'anno, il giorno, e minutamente l'hora mia natia, figurò (sua mercè) il mio Ascendente. . . . Di questi cosí fatti pronostici già ragionandone una mattina col mio molto vertuoso Messer Gabriello Roberti, col qual'io cavalcava da Roma ad Alba, e a Marino via che c'indrizza a Napoli fecessi compagno nostro in cotal camino un Romito."

10 Scardova, L'8 troppo, Dedicatory Letter:

"Sono già alcuni anni, che sulla pietra della virtú fondaste la vostra dotta Academia, la quale e per le lettere Greche e Latine, e per l'altre infinite Scienze, che compiutamente sono in voi, e ch'io non le potrei annoverare ad una, ad una, è divenuta tale, che ben puo stare al paragone di quante hoggidísiano honorate da i piú elevati spirti, o da gli ingegni e piú saggi, e piú pellegrini. Io desiderando di vedere cosí pregiata magnificenza, fui introdotto dal nobilissimo e dottissimo Trasformato, il Signor Cavalliero Gazuoli, specchio della virtú, e lampa del valore. E mirando le grandezze del sublime luoco, scorsi tosto la bella vostra Insegna cio è vidi il gran Padre Prometheo, vostro Protettore, il quale colla Face di fuoco dava spirto alla figura formata dalle sue mani, e tenea sotto e piedi cotal motto: PER QUESTO A MIGLIOR VITA TRASFORMATI. Laudai l'Impresa, e giudicai, levata la corteccia, e il favoloso velo, poco inteso da gli antichi, esso Prometheo non significar altro, che la sembianza del vero DIO ottimo e massimo, e solo Plasmatore dell'huomo, e di tutte le cose humane, e divine. Questa prima mia introduttione fu dell'anno 1543 , sotto il felicissimo Imperio, del molto Illustre Signore, il Signor Conte Tedaldo Canossa, meritissimo Prence di cosí lodevol schiera. Laonde in cosí beato luoco, e ovunque vi truovate, alzate i famosi vostri gridi al cielo, coll'ali della virtú volate là, ove mai non si muore. E di piú con leggiadre Comedie, con sontuosi Conviti, e con facondissime Compositioni, da porre invidia ad ogn'altro bello, e dotto stile, cercate mai sempre di trattenere le nobilissime Reggiane, e fate la lor gloria piú serena, e piú chiara del Sole."

11 Domenichi 238-39: "hebbe Milano anch'egli questi anni a dietro un'altra Academia di nobilissime e virtuosissime persone. . . . Chiamavansi questi gentil'huomini i Trasformati, e portavano per impresa un Platano con un motto. ..."

12 Scardova, L'8 troppo B.iir: “ . . . come dell'Anno M.D.XXXIII alli 17 d'Agosto fu con divotione recitata la Tragedia di San Rocco dalla valorosa Compagnia del detto Santo nella Piazza di Reggio, e fu opra mia, e quei che la recitorno furono tutti 
Gentil'huomini, e de primi della Città, la magior parte de quali anchor vive."

13 Guasco 87-88: (1550) Se giusto è il titolo, per cui li Dottori di Legge Reggiani ripongono ne' loro Annali il sapientissimo nostro Guido Panciroli . . . . Mi è ignoto l'impedimento, per cui non furono stampati gli Annali latini, che di lui abbiamo manoscritti, della città di Reggio: ne' quali narra, quanto è successo dalla Fondazione della medesima, fino all'anno 1560." According to Guasco the historian Panciroli wrote Reggio's Annali from the beginning to 1560.

14 “... furono rappresentate in Reggio com magnifico spettacolo le gesta di S. Rocco; dove fu mirabile vedere nel principio discendere una nube e camparsi in aria; la quale sostenuta con grand'arte da lievi fila che per la loro sottigliezza non potevano vedersi, pareva pender da sé in mezzo al cielo; finalmente, essendone uscita una Vestale ed avendo recitato un apposito prologo, a poco a poco sparendo svaní. Poi un espugnato castello diede imagine con grandissimo diletto degli spettatori d'una vera battaglia; e un finto elefante espresse cosíal naturale i veri movimenti d'un vivo che non solo $\mathrm{i}$ cittadini ma moltissimi forestieri eziandio, ch'erano venuti in folla a vedere, lodarono sommamente quello spettacolo."

15 Guasco 91: "Fu recitata una di lui breve Orazione in occasione della solenne entrata in Reggio, seguita dell'Anno 1560, adi 29 Giugno, del Duca Alfonso Secondo di Ferrara."

16 Panciroli 266-67: "Sotto la volta dell'Arco due donzelle in abito di ninfe sparsero quinci e quindi di fiori la veste d'Alfonso .... . Nell'area innanzi Ia cittadella vedevasi Andromeda fra le Sirene legate allo scoglio. Era mirabil cosa vedere il mostro che usciva dal mare per divorarle, e Perseo sostenuto meravigliosamente in aria dal Pegaso di maniera che potevasi appena vedere con quel ingegno fosse ritenuto come volante per aria. Quindi cessando lo strepito dell'artiglieria, un giovane laureato [lo Scardova] teneva nella destra un dardo e nella sinistra la testa di Medusa disse alcune poche cose in lode d'Alfonso e dell'inclita casa d'Este."

17 Scardova, Due comedie (La nave) 11.12v, 13r: "Appresso di questo i vini di Nicaria ... mi fanno andare in estasi ... potentissima possanza, o dolcissima dolcezza del pretioso, o ottimo vino, ch'io gustai nel porto di Scarpanto. . . . Deh sia pur benedetto Ostro, il cui fiato già una volta mi condusse a Madera, isola ch'è lontana piú di cento miglia da terra ferma. Ivi mangiai le piú grasse quaglie, e le migliori del mondo. Et ivi sono pavoni bianchi, che arrostiti, ne beccarebbono i Re, anzi gli Imperatori se ne leccarebbone sino le dita. Lodo i cavoli, e le rape, e i melloni di Chioggia. Dico ogni bene delle pere, e pomi, e fichi, e di Zafalonia, mi piacciono sommamente le pescaggioni di Stampalia, o meglio mi piaceno quei pesci, quando sono cotti nell'oglio di Corfu, piú che volentieri mangio della Sardella di Lissa, ma o Dei buoni, le carni di Termia sono tali, che a crepapancia ne mangierebbono i piú ghiotti, e i piú leccardi."

18 Scardova, Due comedie Il cornaccione, 1.38v: "Bacco, Bacco, sia sempre ringratiato Bacco, poi c'ho trovato 'I mio fiasco, o quanto sono obligato a questo Dio bono Bacco (secondo c'ho inteso) fu il primo, che trovò la vite, e trovò il vino, la botte, il fiasco, il bottaccio, il boccale, la zucca e mill'altre bone cose tutte utilissime alla vita dell'uomo ... che s'io nol trovava, volea porre a fiamma, e a fuoco tutti questi monti, questi boschi, questi campi, le ville, le case, i tugurij, le capanne, e i pastori. Non volea piú mai che in questi luoghi si trovassero zappe, vanghe, vomeri, e aratri, il che molto sarebbe giovato a coloro, li quali non hanno voglia di lavorare, come non 
ho io."

19 Tasso's Aminta was performed by Gelosi comici on the Belvedere island on the Po river on July 31, 1573.

\section{WORKS CITED}

AGOLINI, Giovanni Battista (rozzo). Il romito. Siena: n.p., 1533.

BARTOLI, Adolfo. Scenari inediti della'Arte. Firenze: Sansoni, 1880.

BEOLCO, Angelo (Ruzante). La pastoral. Ed. Giorgio Padoan. Padova: Antenore, 1978.

CACCIACONTI, Ascanio. Pelagrilli. Siena: Antonio Mazochi, 1544.

CALMO, M. Andrea. Cherebizzi di $M$.... Ne' quali si contengono varii, et ingeniosi discorsi, e fantastiche fantasie filosofiche, compresi in piú lettere volgari, nella lingua antica dechiariti. Vinegia: Domenico De' Farri, 1559.

. Le giocose moderne et facetissime egloghe pastorali, sotto bellissimi concetti, in nuovo sdrucciolo, in lingua materna. Vinegia: Iovambattista Bertacagno, 1553.

CARRARA, Enrico. La poesia pastorale. Milano: Vallardi, 1909.

Centro Studi sul Teatro Medioevale e Rinascimentale. Origini del Dramma Pastorale in Europa Convegno di Studi Viterbo 31 maggio-3 giugno 1984 a c. di M. Chiabo e F. Doglio. Viterbo, 1985.

CROCIONI, Giovanni. "per una fonte dell'Aminta." Rivista d'Italia 12 (1909).

"Pietro Martire Scardova". La bibliofilia 11 (1909-1910).

DOMENICHI, Lodovico. Ragionamento. Ed. Stephen Orgel. New York and London: Garland Publishing, Inc., 1979.

FLAMINI, Francesco. Il Cinquecento Storia Letteraria d'Italia. Milano: Vallardi, n.d. FONTANINI, Giusto. Biblioteca dell' Eloquenza Italiana. Con le annotazioni del signor Apstolo Zeno. Venezia: Pasquali, 1753.

GIRARDI CINZIO, Gian Battista."Discorso intorno il comporre le satire atte alla scena." Scritti critici, ed. Camillo Guerrieri Crocetti. Milano: Marzorati, 1973.

GUASCO, Giovanni. Storia Litteraria Del Principio, e Progresso Dell Academia Di Belle Lettere in Reggio. Reggio: Ippolito Vedrotti, 1711.

KENNEDY, William J. Jacopo Sannazaro and the uses of Pastoral. Hanover and London: U P of New England, 1983.

LANDO, Ortensio. Paradossi, cioe, Sententie fuor del Commun parere novellamente venute in luce. Lione: Gioanni Pullon da Trino, 1543.

NERI, Ferdinando. Scenari delle Maschere in Arcadia. Città di Castello: S.Lapi, 1913.

PANCIROLI, Guido. Storia della Cittd di Reggio tradotta da latino in volgare da Prospero Viani. Reggio: G. Barbieri e Soc. Editori, 1846.

PIERI, Marzia. La scena boschereccia nel Rinascimento italiano. Padova: Liviana, 1983. ROMAGNOLI, Sergio e GARBERO, Elvira. Teatro a Reggio Emilia. Firenze: Sansoni, 1980.

SCARDOVA, Pietro Martire. Due comedie di M. Pietro Martire Scardova Canonico di

Reggio, l'una marittima detta La nave, l'altra pastorale, chiamata Il cornacchione, amendue fuora del uso comune. Bologna: Anselmo Giaccarelli, 1554.

L' 8 troppo del Reverendo Canonico di Reggio Messer Pietro Martire Scardova. Parma: Seth Viotto, 1550.

SERLIO, Sebastiano. "the Second Book of Architecture." In the Renaissance Stage. Ed. 
B. Hewill. Florida: U of Miami P, 1958.

TIRABOSCHI, Girolamo. Biblioteca Modenese. Modena: Socictà Tipografica, 1784. . Storia della Letteratura Italiana. Venezia, 1796 Con Privilegio.

TREGIANI, Domenico Di Gismondo (Desioso Academico Insipido). Il ladro cacco.

Venetia: G.B. Ciotti, 1583. Rpr. of $1543 \mathrm{ed}$.

ZORZI. Ludovico. "Intorno alla Commedia dell'Arte." Forum Italicum, 14 (1980).

\section{APPENDIX}

\section{SCHEMA DI CANOVACCIO TIPO}

Parti Fisse
* Magnifico
- Innamorata(2)
- Innamorato(1)
* Zanni(2)
* Servetta

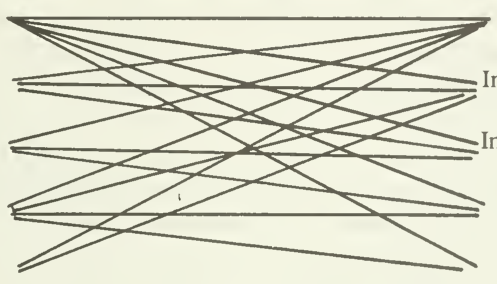

Capitano
Dottore * Innamorata(1) • Innamorato(2) • Zanni(1) * Cortigiana *

Parti Mobili

- = parti serie

* = parti comiche

Fig. 1. Canovaccio from Zorzi. 